Pol. J. Food Nutr. Sci., 2019, Vol. 69, No. 3, pp. 247-254 DOI: $10.31883 /$ pjfns/109666 http://journal.pan.olsztyn.pl

Original research article

Section: Food Quality and Functionality

\title{
Fat from Tenebrionidae Bugs - Sterols Content, Fatty Acid Profiles, and Cardiovascular Risk Indexes
}

\author{
Jiří Mlček ${ }^{1 *}$, Anna Adámková ${ }^{1}$, Martin Adámek ${ }^{2}$, Marie Borkovcová ${ }^{1}$, Martina Bednářová ${ }^{3}$, Ivana Knižková ${ }^{4}$ \\ ${ }^{1}$ Department of Food Analysis and Chemistry, Tomas Bata University, Zlin, Czech Republic \\ ${ }^{2}$ Department of Microelectronics, Faculty of Electrical Engineering and Communication, \\ Brno University of Technology, Czech Republic \\ ${ }^{3}$ Department of Information Technology, Mendel University, Brno, Czech Republic \\ ${ }^{4}$ Livestock Technology and Management, Institute of Animal Science, Prague, Czech Republic
}

Key words: mealworm, superworm, cholesterol, stigmasterol, $\beta$-sitosterol, cholecalciferol

This work focused on analysing the content of selected sterols and profile of fatty acids of edible insect species - mealworm (Tenebrio molitor) and superworm (Zophobas morio), which are expected to increase their usability in human nutrition. Sterols content was determined using capillary gas chromatography method. Cholesterol content was determined at $1335 \mathrm{mg} / \mathrm{kg}$ in dry matter (DM) for the mealworm, which was less than for superworm $(3224 \mathrm{mg} / \mathrm{kg} \mathrm{DM})$. Other sterols analysed were stigmasterol and $\beta$-sitosterol, which were once again higher in superworm (stigmasterol - $44 \mathrm{mg} / \mathrm{kg} \mathrm{DM}$ and $\beta$-sitosterol - $414 \mathrm{mg} / \mathrm{kg} \mathrm{DM}$ ) than in mealworm (stigmasterol - $18 \mathrm{mg} / \mathrm{kg} \mathrm{DM}$ and $\beta$-sitosterol - $171 \mathrm{mg} / \mathrm{kg} \mathrm{DM}$ ). From the nutritional point of view, the amount of cholecalciferol is also not negligible, which was $190 \mu \mathrm{g} / \mathrm{kg}$ DM in mealworm and $199 \mu \mathrm{g} / \mathrm{kg} \mathrm{DM}$ in superworm. Atherogenic index (AI), thrombogenic index (TI), and cholesterol index (CSI) were calculated for both species and compared with the results of other authors. These indexes are often considered predictors of cardiovascular diseases. A potential benefit of both species could be the balanced proportion of sterols of animal and plant origin that could be nutritionally well-accessible and lower weight of dry matter necessary to consume to cover the daily dose of linoleic acid compared to dried beef.

\section{INTRODUCTION}

From the nutritional point of view, edible insects have become an increasingly discussed topic in both the professional and laic public, even in countries where their consumption is not common [Mlček et al., 2014; Ramos-Elorduy et al., 2011; van Huis, 2016]. In particular, it is possible to use edible insects as a valuable alternative source of proteins, especially in regions with a lack of conventional animal proteins [Mlček et al., 2014; Ramos-Elorduy et al., 2011; van Broekhoven et al., 2015]. Other benefits include higher feed conversions, low greenhouse gas emissions, better soil utilization, and the conversion of organic materials to valuable products. This strategy can lead to financial savings and environmental benefits [Cerritos, 2009, 2011; Fontaneto et al., 2011; Mariod et al., 2011; Premalatha et al., 2011]. Insects have also a great potential as feed, for example, in aquaculture [van Huis, 2016]. This is due to the high content of proteins and sulphur amino acids that can be successfully used as feed for poultry [Józefiak et al., 2016].

One of the most studied species of insects is the mealworm [Finke, 2002, 2004; Barroso et al., 2014; Ravzanaadii et al.,

\footnotetext{
* Corresponding Author: Tel.: +42-057-603-3030;

E-mail: mlcek@ft.utb.cz (J. Mlček)
}

2012; Sánches-Muros et al., 2016; Tzompa-Sosa et al., 2014; Zielińska et al., 2015]. It is a good source of protein and fat. The highest protein content $(637.0-676.5 \mathrm{~g} / \mathrm{kg}$ in dry matter (DM)) and lowest fat content (148.8-184.0 g/kg DM) was determined in adult specimen. However, larvae and pupae are more nutritionally beneficial because of their better digestibility and sensory properties. For larvae, the total protein content is usually reported in the range from 477.6 to $527.0 \mathrm{~g} / \mathrm{kg}$ DM and total fat content from 189.0 to $382.9 \mathrm{~g} \mathrm{~kg} \mathrm{DM.}$

Sterols are key nutritional elements of insects. They are precursors of steroid hormones and development process regulators [Mondy et al., 2006]. Phytosterols, typical plant sterols, were found in insect samples [Piironen, 2000], because insects cannot synthesize cholesterol de novo [Behmer $\&$ Nes, 2003] and have to use plant phytosterols ( $\beta$-sitosterol, campesterol, stigmasterol) to synthesize cholesterol. Cholesterol is the most abundant sterol present in insects. Mealworm (Tenebrio molitor) sterols contain about $17 \%$ of 7 -dehydrocholesterol and about $67 \%$ of cholesterol [Ikekawa et al., 2013]. Insects need cholesterol to synthesize vitamin $\mathrm{D}_{3}$ and steroid hormones known as ecdysteroids. These hormones are indispensable for the individual developmental stages of the instar [Nation, 2001; Klowden, 2007].

Cholesterol is found in foods of animal origin, but it is also the only sterol the human body can synthetize by itself. Too high cholesterol intake causes increased levels of low-density 
lipoprotein (LDL) and very low-density lipoprotein (VLDL), which results in an increased risk of the development of the metabolic syndrome (obesity, diabetes mellitus, cardiovascular disease) [WHO, 2004]. The human body consumes about $2 \mathrm{~g}$ of cholesterol per day. The optimal intake is 0.15 $-0.3 \mathrm{~g}$ per day. This amount is sufficient because the rest is produced in the body through endosynthesis. However, common diet means an intake of $0.6-0.8 \mathrm{~g}$ of cholesterol. A suitable diet can reduce cholesterol by $10 \%$, e.g. by consumption of fiber, antioxidants, and phytosterols [Pánek et al., 2002].

Vitamin D is synthesized in the human body from ergosterol and 7-dehydrocholesterol by exposure to sunlight. In the latitudes of the temperate zone, sunlight does not cover these needs and vitamin D endosynthesis is insufficient. For this reason, it is necessary to supplement it. Vitamin D, along with calcitonin and parathormon hormones, controls the calcium and phosphorus metabolism. Its deficiency leads to rachitis in children, while older people develop osteopenia and consequently osteoporosis [Pánek et al., 2002]. For this reason, the recommended daily dose of vitamin $\mathrm{D}$ is $5 \mu \mathrm{g} /$ day [Decree No. 225/2008 Coll, 2008].

Developmental stage of insect is one of the major factors influencing the amount of fat and the fatty acids [Nowak et al., 2016; Finke, 2004; Adámková et al., 2016]. Other factors include gender, diet and the environment [Chakravorty et al., 2011, 2014, 2016]. Fatty acid profile description can be simplified and expressed by various proportional numbers, including the cholesterol index (CSI), the atherogenic index (AI), and the thrombogenic index (TI). These indexes serve often in medicine as important predictors of cardiovascular risks [Dobiášová, 2006]. Regarding the $n-3: n-6$ ratio of fatty acids and the mentioned indexes, edible insect fat may have a protective effect on human health. One of the objectives of this study was to determine the ratio of $n-3: n-6$ fatty acids and CSI, AI, and TI in edible insect fat and to compare them with other commodities of animal origin.

The content of sterols in the mealworm (Tenebrio molitor) and superworm (Zophobas morio) bred on farms in the Czech Republic, which are fed ad libitum with conventional feed, is not yet sufficiently known from available literature [Sabolová et al., 2016] and so far this issue has not been thoroughly explored. The amount of cholesterol and phytosterols can be affected by long-term nutritional stress (the insects do not have access to feed). Although insects bred in farms usually do not starve, access to feed may be restricted during longer transport or longer pre-treatment before killing.

This study was carried out to define initial information on the content of cholesterol, phytosterols, and fatty acids in $T e$ nebrioidae larvae and their presumed impact on human health (AI, TI and CSI). Furthermore, the impact of the nutritional stress (inaccessibility of the feed) on the cholesterol content was evaluated, as the nutritional stress has a significant impact on the welfare of the breed.

\section{MATERIAL AND METHODS}

\section{Material}

Species used for analysis were mealworm larvae (Tenebrio molitor) and superworm larvae (Zophobas morio). Samples were purchased from breeder Radek Frýželka, Brno, Czech Republic. Insects were reared in optimum conditions for the development of individual species (mealworm $-25-28^{\circ} \mathrm{C}$, $60-70 \%$ relative humidity $(\mathrm{RH})$; superworm $-28-30^{\circ} \mathrm{C}, 60$ $-70 \% \mathrm{RH}$ ) and fed with wheat bran and oat bran ad libitum till the beginning of the experiment.

At the beginning of the experiment, two groups of live larvae, weighing approximately $200 \mathrm{~g}$, were taken from a breeding. The first group was left to starve for $12 \mathrm{~h}$. According to the European Food Safety Authority (EFSA) recommendations [EFSA, 2015], the expiration time is $12-24 \mathrm{~h}$. To shorten the processing, the lower limit was chosen. Subsequently, the insects were killed in boiling water $\left(100^{\circ} \mathrm{C}\right)$ and dried at $105^{\circ} \mathrm{C}$. Subsequently, the samples were homogenized and stored in a hermetically sealed aseptic box with a normal atmosphere at $4-7^{\circ} \mathrm{C}$ until analysis.

The second experimental group of larvae starved for $168 \mathrm{~h}$ (7 days) before killing, which led to nutritional stress. Furthermore, the larvae were killed and processed in the same way as the first experimental group of larvae.

Wheat bran with the following nutritional values (data per $100 \mathrm{~g}$ of product) were used as feed: energy $1210 \mathrm{~kJ} / 292 \mathrm{kcal}$, fats $5.3 \mathrm{~g}$, of which saturated fatty acids accounted for $0.88 \mathrm{~g}$, carbohydrates $24.9 \mathrm{~g}$, of which sugars were at $2.2 \mathrm{~g}$, fiber $40.2 \mathrm{~g}$ and protein $16.2 \mathrm{~g}$, and salt $0.1 \mathrm{~g}$.

Oat bran with the following nutritional values (data per $100 \mathrm{~g}$ of product) were used as feed: energy $1518 \mathrm{~kJ} / 361 \mathrm{kcal}$, fats $8.3 \mathrm{~g}$, of which saturated fatty acids accounted for $1.4 \mathrm{~g}$, carbohydrates $45 \mathrm{~g}$, of which sugars were at $2.0 \mathrm{~g}$, fiber $12 \mathrm{~g}$ and protein $21.0 \mathrm{~g}$, and salt $0.01 \mathrm{~g}$.

\section{Determination of dry matter content of infrared scales}

A homogenized sample of about $0.5 \mathrm{~g}$ was evenly distributed over the aluminium foil and subsequently analysed according to ISO 1442:1997 using Precisa HA 300 scales with infra radiator (Precisa Gravimetrics AG, Dietikon, Schweiz). In this method, the test sample is heated and the weight loss is measured. The basis of the method is the drying of the sample by infrared rays. Drying was carried out at $105^{\circ} \mathrm{C}$ until constant weight, where the difference of two consecutive weights was not less than $2 \mathrm{mg}$ per min.

\section{Crude protein content determination}

The nitrogen and crude protein were analysed using the Kjeldahl's method [ISO 1871:2009]. The samples (1 g) and blank runs were mineralized at $420^{\circ} \mathrm{C}$ for $105 \mathrm{~min}$. The distillation was performed on Kjeltec ${ }^{\mathrm{TM}} 2200$ (FOSS, Denmark) for $4 \mathrm{~min}$. The protein content was calculated using nitrogen-to-protein conversion factor of 6.25 .

\section{Fat content determination}

The fat was extracted acc.to Soxhlet's method [Soxhlet, 1879] on the Gerhardt Soxtherm (C. Gerhardt GmbH \& Co. $\mathrm{KG}$, Germany). The sample (5 g) was placed in the extraction capsule and extracted (program selected: $70^{\circ} \mathrm{C}$ for $120 \mathrm{~min}$ ) with $150 \mathrm{~mL}$ of petroleum ether (Ing. Petr Švec - PENTA s.r.o., Prague, Czech Republic). The extracted sample was then dried at $103^{\circ} \mathrm{C}$ and repeatedly weighed until a constant 
weight (difference between two subsequent weighings of less than $10 \mathrm{mg}$ ) was achieved.

\section{Sterols content determination}

Sterols in fat of the samples were analysed and evaluated in an accredited laboratory Skúšobňa VETLAB, Ltd., Púchov, Slovakia. Determination of sterols content was done using capillary gas chromatography method according to ES no 213/2001 [Regulation (EC) No. 2013/2001, 2001].

\section{Cholecalciferol (vitamin $D_{3}$ ) content determination}

Cholecalciferol content determination was done according to EN 12821:2009 [EN 12821:2009, 2009]. Samples were extracted with hexane. Determination of vitamin $\mathrm{D}_{3}$ content was performed using semi-preparative HPLC on normal phase followed by analytical reverse phase HPLC. Vitamin D was detected spectrophotometrically in the UV area. When determining vitamin $\mathrm{D}_{3}$, vitamin $\mathrm{D}_{2}$ was used as an inner standard.

\section{Fatty acid profile determination}

Weighted portions of fat $(0.5 \mathrm{~g})$ extracted from worms were esterified according to the ISO 12966-2: 2011 [ISO 12966-2:2011, 2011] using $0.25 \mathrm{~mol} / \mathrm{L}$ of methanolic potassium hydroxide.

Fatty acid methyl esters in the samples were determined using gas chromatography with a flame ionization detector (GC/FID) on GC-2010 (Shimadzu, Kyoto, Japan), using a high polar chromatography column HP-88 (100 m $\times$ $0.25 \mathrm{~mm} \times 0.2 \mu \mathrm{m})$ (Agilent Technologies, CO, Santa Clara, USA), which is intended for the identification of cis/trans fatty acid methyl esters. Chromatographic conditions were as follows: inlet volume $-1 \mu \mathrm{L}$; inlet temperature $-250^{\circ} \mathrm{C}$; split ratio - 1:100; carrier gas - nitrogen; and temperature program - $80^{\circ} \mathrm{C} / 5 \mathrm{~min}, 200^{\circ} \mathrm{C} / 30 \mathrm{~min}, 250^{\circ} \mathrm{C} / 15 \mathrm{~min}$. Quantitative evaluation of the individual fatty acid contents in the samples was performed using the internal normalization method using FAME Mixture C4-C24 (Supelco Inc, Bellefonte, USA) containing 37 selected fatty acid methyl esters. The content of individual fatty acids was calculated as a percentage of the total methyl ester present.

\section{Lipid nutritional quality indices evaluation}

For each species, the atherogenicity index (AI) and thrombogenicity index (TI) were calculated according to the following formulas [Zhang et al., 2014; Kulma et al., 2016]:

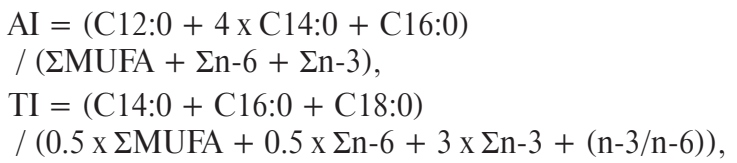

where: MUFA stands for Mono Unsaturated Fatty Acids. These indexes were further calculated for both animal species from the fatty acid profiles from available literature.

The cholesterol-saturated acid index (CSI) was determined in larvae of mealworm fed ad libitum according to the following formula [Pánek, 2002]:
$\mathrm{CSI}=1.01 \times \Sigma \mathrm{SFA}(\mathrm{g} / 100 \mathrm{~g})$

$+50 \times$ cholesterol $(\mathrm{g} / 100 \mathrm{~g})$,

where: SFA stands for Saturated Fatty Acids.

\section{Statistical analysis}

Each measurement was performed 4 times. All samples were from the same batch. The data was analysed using Excel 2013 (Microsoft Corporation, Redmond, USA) and STATISTICA Cz version 12 (StatSoft, Inc., Tulsa, USA). Results were expressed by average and standard deviation. Comparison of the results was performed using a Kruskal-Wallis test $(\alpha=0.05 ; \alpha=0.01)$.

\section{RESULTS AND DISCUSSION}

To determine the basic characteristic and describe the material in mealworm (Tenebrio molitor) and superworm (Zophobas morio) bred in the Czech Republic, the following basic components were evaluated: dry matter (DM), crude protein in DM, and fat in DM (Table 1). Further description of the material is given in Adámková [2017].

The cholesterol content in mealworm (Tenebrio molitor) and superworm (Zophobas morio) fed ad libitum and these under nutritional stress (Table 2); and contents of stigmasterol, $\beta$-sitosterol, and cholecalciferol in the ad libitum-fed larvae (Table 3) were analysed.

The average cholesterol content in the ad libitum-fed mealworm larvae (Tenebrio molitor) was $1335 \mathrm{mg} / \mathrm{kg}$ DM. Superworm larvae (Zophobas morio) fed ad libitum contained higher amount of cholesterol (3224 mg/kg DM). Compared with the results of samples that have been subjected to nutritional stress, cholesterol levels were higher in the ad libitum fed larvae (Table 2). Statistically significant $(p<0.01)$ difference was detected between the worms without nutritional

TABLE 1. Composition of material from mealworm (Tenebrio molitor) and superworm (Zophobas morio) bred in the Czech Republic - dry matter (DM), crude protein in DM and fat in DM.

\begin{tabular}{lcc}
\hline Components & Zophobas morio & Tenebrio molitor \\
\hline DM (g/100 g) & $47.9 \pm 0.6$ & $32.6 \pm 0.7$ \\
Crude protein (g/100 g DM) & $39.4 \pm 0.1$ & $62.6 \pm 0.4$ \\
Fat (g/100 g DM) & $39.1 \pm 0.4$ & $16.7 \pm 0.1$ \\
\hline
\end{tabular}

DM - dry matter.

TABLE 2. Cholesterol content in dry matter of mealworm (Tenebrio molitor) and superworm (Zophobas morio) fed ad libitum and under nutritional stress.

\begin{tabular}{lcc}
\hline Nutrition of larvae & Tenebrio molitor & Zophobas morio \\
\hline Ad libitum $(\mathrm{mg} / \mathrm{kg})$ & $1335 \pm 28^{\mathrm{Ab}}$ & $3224 \pm 35^{\mathrm{Aa}}$ \\
Nutritional stress $(\mathrm{mg} / \mathrm{kg})$ & $1124 \pm 24^{\mathrm{Bb}}$ & $2985 \pm 31^{\mathrm{Ba}}$ \\
\hline
\end{tabular}

$\mathrm{A}, \mathrm{B}$ - means with different letters in the same column are significantly different at $\mathrm{p}<0.01 ;{ }^{\mathrm{a}, \mathrm{b}}$ - means with different letters in the same row are significantly different at $\mathrm{p}<0.01$ 
stress and these subjected to nutritional stress. The influence of insect species on sterol content was highly statistically significant. The level of significance was found to be $p<0.01$.

Cholesterol is supposed to be burnt up in nutritional stress to preserve life functions and eventually to build up the ecdysteroid needed for molting. Other available literature does not provide detailed information on cholesterol content depending on the nutritional stress and the stage of larval development in species we analysed. Sabolová et al. [2016] listed a number of selected sterols in farm insects from Sumatra Island and these kept under European conditions. In superworm from Sumatra, the authors demonstrated sterols content at $1784.1 \mathrm{mg} / \mathrm{kg}$ DM and in these from Czech Republic at $1594.9 \mathrm{mg} / \mathrm{kg}$ DM. These values are lower than in our work, but higher than those detected in the same species by Ramos-Bueno et al. [2016], i.e. $185 \mathrm{mg} / \mathrm{kg}$ DM. Different values can be caused by nutrition because cholesterol is not synthesized de novo, but the intake is dependent on the composition and dose of feed. Similar factors may influence the cholesterol levels in mealworm, in which Ramos-Bueno et al. [2016] determined cholesterol content at $726 \mathrm{mg} / \mathrm{kg}$ DM. In turn, Sabolová et al. [2016] reported $669.4 \mathrm{mg} / \mathrm{kg} \mathrm{DM}$ for the same species bred in Sumatra. These values are again lower than in our work.

Ekpo et al. [2009] evaluated cholesterol content in fats of termites (Macrotermes bellicosus) and caterpillars (Imbrasia Belina). They found out that the average cholesterol content in their lipid fraction was up to $3.6 \%$.

Cholesterol content in mealworm (Tenebrio molitor) detected in our work is comparable with some other commodities of animal origin, e.g. lobster (1460 mg/kg). Superworm (Zophobas morio) is comparable to carp $(3540 \mathrm{mg} / \mathrm{kg}$ ), i.e. an animal commodity considered a valuable source of nutrients and liver (up to $3450 \mathrm{mg} / \mathrm{kg}$ ) [Velíšek, 2002; Venugopal \& Gopakuma, 2017].

In comparison with other commodities, the species had higher cholesterol levels than most of the foods of animal origin. Cholesterol content in mealworm can be compared to beef tallow, mayonnaise, and Lobster (northern) and it is between the values for butter and whole eggs [Velíšek, 2002; Venugopal \& Gopakuma, 2017]. The recommended dietary allowance for cholesterol consumption is $300 \mathrm{mg} /$ day for adult man [EFSA, 2010]. To achieve this level, the amount of evaluated insects that would have to be consumed is $93 \mathrm{~g}$ for superworm and $224 \mathrm{~g}$ for mealworm. However, it is assumed that normally such a quantity is not consumed in the dried state, as it is not expected for a large quantity of eggs to be eaten each day. To fill the RDA (Recommended Dietary Allowances) when eating eggs, $75 \mathrm{~g}$ of the whole egg (about 1.5 eggs day) is needed.

On the other hand, the edible insects analysed contained phytosterols (stigmasterol and $\beta$-sitosterol) (Table 3), which serve as cholesterol antagonists, thus balancing the sterol levels. While comparing the species, a statistically significant $(\mathrm{p}<0.01)$ difference was detected for stigmasterol and $\beta$-sitosterol. Compared with the samples from Sumatra, which were analysed by Sabolová et al. [2016], the stigmasterol content was found to be up to 4 times higher. On the contrary, Sabolová et al. [2016] detected no stigmasterol in the edible insects from the Czech Republic. In the case
TABLE 3. Content of selected sterols and cholecalciferol in dry matter of mealworm (Tenebrio molitor) and superworm (Zophobas morio) larvae fed ad libitum.

\begin{tabular}{lcc}
\hline Compounds & Tenebrio molitor & Zophobas morio \\
\hline Stigmasterol (mg/kg) & $18 \pm 6^{\mathrm{b}}$ & $44 \pm 12^{\mathrm{a}}$ \\
$\beta$-Sitosterol $(\mathrm{mg} / \mathrm{kg})$ & $171 \pm 20^{\mathrm{b}}$ & $414 \pm 37^{\mathrm{a}}$ \\
$\begin{array}{l}\text { Vitamin } \mathrm{D}_{3}(\text { cholecalciferol) } \\
(\mu \mathrm{g} / \mathrm{kg})\end{array}$ & $190 \pm 20^{\mathrm{a}}$ & $199 \pm 25^{\mathrm{a}}$ \\
\hline $\begin{array}{l}\text { a,b }- \text { means with different letters in the same row are significantly different } \\
\text { at } \mathrm{p}<0.01 .\end{array}$
\end{tabular}

of $\beta$-sitosterol in the mealworm, the content detected in this work was lower than that measured by Sabolová et al. [2016]. $\beta$-Sitosterol content of the superworm measured by Sabolová et al. [2016] was lower than the content detected in this work at both sites of origin. In general, nutritional values may depend on feed and living conditions [Ghosh et al., 2017]. E.g. Van Broekhoven et al. [2015] demonstrated a fat content in the range from 32.8 to $43.5 \%$, depending on the mealworm feed. Oonincx [2015] reported the influence of feed on nutritional values (fat, protein, fatty acid profiles, and selected minerals) under the same breeding conditions of the same species. For this reason, the sterol content can be assumed to vary depending on nutrition and living conditions.

Although common commodities of plant origin have a higher total phytosterol content, some commodities are comparable in their phytosterols content to edible insects (e.g. corn oil $590 \mathrm{mg} / \mathrm{kg}$, palm oil 376-627 mg/kg) [Velíšek, 2002]. For this reason, edible insects may be found comparable with commodities of plant origin. The content of stigmasterol ranges from $0 \%$ to $20 \%$ of all sterols in vegetable oils, while that of $\beta$-sitosterol is up to $62 \%$ of all sterols in these commodities [Velíšek, 2002].

When comparing the amount of cholecalciferol, the values are comparable despite the difference in the total content of sterols $-190 \mu \mathrm{g} / \mathrm{kg}$ in mealworm and $199 \mu \mathrm{g} / \mathrm{kg}$ in superworm. Cholecalciferol content in the analysed samples is at least three to four times higher than that of other commodities of animal origin (except for fish), e.g. $3 \mu \mathrm{g} / \mathrm{kg}$ in meat, $10-20 \mu \mathrm{g} / \mathrm{kg}$ in butter, and 30-50 $\mu \mathrm{g} / \mathrm{kg}$ in eggs [Velíšek, 2002]. A comparable content of cholecalciferol with the analysed samples is stated by Velíšek [2002] for sea fish $(50-450 \mu \mathrm{g} / \mathrm{kg})$. Edible insects can therefore be a good source of cholecalciferol and consequently meet the recommended daily dose for this compound. In practice, this means consuming approximately $25 \mathrm{~g}$ of dried mealworm or superworm to cover the required dose of cholecalciferol.

From the nutritional point of view, the profile of lipids and the content of individual fatty acids is important, as pointed out by the WHO [Zielinská et al., 2015]. Table 4 shows the fatty acid profile of the two insect species, where the superworm has a higher saturated fatty acid content of the total fatty acid content of more than $13 \%$ than mealworm. This material is therefore more advantageous in terms of technological processing. However, dried material from mealworm, which has higher MUFA and PUFA contents, is more suitable to prevent civilization diseases. 
TABLE 4. Fatty acid composition in mealworm (Tenebrio molitor) and superworm (Zophobas morio) bred in the Czech Republic (\% of total fatty acids).

\begin{tabular}{lcc}
\hline Fatty acid & Zophobas morio & Tenebrio molitor \\
\hline C12:0 & $0.1 \pm 0.00$ & $0.2 \pm 0.03$ \\
C14:0 & $1.3 \pm 0.04$ & $3.5 \pm 0.03$ \\
C16:0 & $32.3 \pm 0.01$ & $18.6 \pm 0.08$ \\
C17:0 & $0.9 \pm 0.04$ & $0.3 \pm 0.02$ \\
C18:0 & $8.2 \pm 0.10$ & $6.7 \pm 0.46$ \\
C20:0 & $0.3 \pm 0.02$ & $0.3 \pm 0.08$ \\
\hline SFA sum & 43.0 & 29.7 \\
\hline C16:1 (cis-9) & $0.6 \pm 0.05$ & $1.4 \pm 0.07$ \\
C18:1 (cis-9) & $32.4 \pm 0.01$ & $36.9 \pm 1.53$ \\
\hline MUFA sum & 33.0 & 38.3 \\
\hline C18:2 (cis-9.12) & $23.4 \pm 0.15$ & $30.9 \pm 1.08$ \\
C18:3 (cis-9.12.15) & $0.6 \pm 0.01$ & $1.1 \pm 0.03$ \\
\hline PUFA sum & 24.0 & 32.0 \\
\hline$n$-3 sum & 0.6 & 1.1 \\
$n-6$ sum & 23.4 & 30.9 \\
\hline SFA - saturte & &
\end{tabular}

SFA - saturated fatty acids, MUFA - monousaturated fatty acids, PUFA - polyunsaturated fatty acids
Differences in the fatty acid profile against other authors in the mealworm are, for example, in the content of oleic acid, which was determined in this work by almost $7 \%$ lower than in Ravzanaadii et al. [2012] and more than $13 \%$ than that found by Tzompa-Sosa et al. [2014]. These authors reported also a lower percentage of linoleic acid - up to $8 \%$ than in our study. In superworm, there are differences in the fatty acid profile, for example, in oleic acid content, where the difference is up to $7 \%$ and in linoleic acid content - up to $4 \%$ against the value reported by Finke [2002]. The sample was similar in values to that of Barroso et al. [2014]. Differences between the above nutritional values in this work and the other sources may be due to different breeding conditions.

The cholesterol-saturated acid index was 36.6 for mealworm and 59.5 for superworm. The CSI values for mealworm are comparable to the CSI value of goose and duck fat, and for the superworm these values correspond to the bovine tallow [Pánek et al., 2002]. Ramos-Bueno et al. [2016] analysed fatty acid profile and cholesterol content in seven insect species, and calculated CSI from these data, which reached 27.5 for mealworm and 46.3 for superworm. These values are lower than the values calculated in the samples analysed in our study. This may be due to different feeds administered.

The AI, TI, and $n-3: n-6$ ratio are determined in fats to evaluate their health effects. The atherogenic index was lower in mealworm than in superworm (Table 5). A similar trend was also found in the thrombogenic index, which is almost twice as low in mealworm.

The AI, TI and n-3:n-6 ratio were calculated from fatty acid profiles of other authors to enable comparison (Table 5),

TABLE 5. Atherogenicity index (AI), thrombogenicity index (TI) and $n-3: n-6$ ratio in mealworm (Tenebrio molitor) and superworm (Zophobas morio) bred in the Czech Republic with values calculated from the fatty acid profile measured by other authors (\% of total fatty acids).

\begin{tabular}{|c|c|c|c|c|c|}
\hline Stage & Origin & $n-3: n-6$ & $\mathrm{AI}$ & $\mathrm{TI}$ & References \\
\hline \multicolumn{6}{|c|}{ Zophobas morio } \\
\hline Larvae & Czech Republic & 0.027 & 0.7 & 1.4 & This study \\
\hline Larvae & Spain & 0.045 & 0.7 & 1.4 & Ramos-Bueno et al. [2016] \\
\hline Larvae & USA & 0.033 & 0.6 & 1.3 & Finke [2002] \\
\hline Larvae & Spain & 0.062 & 0.6 & 1.2 & Barroso et al. [2014] \\
\hline \multicolumn{6}{|c|}{ Tenebrio molitor } \\
\hline Larvae & Czech Republic & 0.036 & 0.5 & 0.8 & This study \\
\hline Larvae & Spain & 0.05 & 0.4 & 0.5 & Ramos-Bueno et al. [2016] \\
\hline Larvae & USA & 0.04 & 0.4 & 0.6 & Finke [2002] \\
\hline Adult & USA & 0.029 & 0.4 & 0.7 & Finke [2002] \\
\hline Larvae & Republic of Korea & 0.045 & 0.4 & 0.5 & Ravzanaadii et al. [2012] \\
\hline Adult & Republic of Korea & 0.023 & 0.4 & 0.7 & Ravzanaadii et al. [2012] \\
\hline Larvae & Spain & 0.036 & 0.3 & 0.5 & Sánches-Muros et al. [2016] \\
\hline Larvae & Spain & 0.036 & 0.3 & 0.5 & Barroso et al. [2014] \\
\hline Not specified & Netherlands & 0.038 & 0.4 & 0.6 & Tzompa-Sosa et al. [2014] \\
\hline Larvae & Poland & 0.054 & 0.4 & 0.6 & Zielińska et al. [2015] \\
\hline
\end{tabular}


as the indices themselves have not yet been presented in the available literature. The AI and TI determined by other authors were lower than in our work. AI in our research was 0.7 for mealworm, while it was 0.6 acc. to both Finke [2002] and Barroso et al. [2014]. For superworm, the calculated AI ranged between 0.3 and 0.4 [Finke, 2002; Ravzanaadii et al., 2012; Sánchez-Muros et al., 2016; Tzompa-Sosa et al., 2014; Zielińska et al., 2015]. Our results were slightly higher (0.5). The situation was similar for TI. It calculated values ranged from 1.2 to 1.3 for mealworm and from 0.5 to 0.7 for superworm [Finke, 2002; Barroso et al., 2014; Ravzanaadii et al., 2012; Sánchez-Muros et al., 2016; Tzompa-Sosa et al., 2014; Zielińska et al., 2015]. In our work, TI was again slightly higher for both analysed species.

Edible insect fat can be compared to the fat of beef or pork or to vegetable margarine [Stajić et al., 2011]. The thrombogenic index for superworm (1.4) can be compared with these fats again, but the thrombogenic index of mealworm is similar to that of chicken meat fat. The calculated atherogenic index of the profiles reported by other authors can be compared with polyunsaturated acids of margarines, its value is similar to that of olive oil. Taking into account the risk of cardiovascular disease, the consumption of the mealworm is more favourable.

Another important factor describing the risk of the metabolic syndrome arising from fat consumption is the evaluation of the ratio of $n-3$ and $n-6$ fatty acids, which, according to WHO recommendations should be $1: 2$ to $1: 6$ [Mourek \& Mourek, 2011; Jirák \& Zeman, 2007]. The real n-3:n-6 ratio is normally $1: 15$ in the diet of the Western civilization, as reported by Simopoulos [2002]. The ratio determined for our samples (Table 5) as well as for the values calculated by other authors is higher than this. Although this ratio is not too favorable for the consumption of edible insect fats, the other parameters observed in this work balance this drawback.

The Scientific Opinion on Dietary Reference Values for fats, including saturated fatty acids, polyunsaturated fatty acids, monounsaturated fatty acids, trans fatty acids, and cholesterol [EFSA, 2010] does not mention the recommendation for $n-6: n-3$ ratio. According to this material, linoleic acid intake should not fall below $4 \%$ and that of linolenic acid below $0.5 \%$ of total energy intake. An average man with light work has a total energy intake of $10,000 \mathrm{~kJ}$ and should receive $400 \mathrm{~kJ}$ of linoleic acid and $50 \mathrm{~kJ}$ of linolenic acid. Assuming an energy value of $37.6812 \mathrm{~kJ} / \mathrm{g}$, it is possible to calculate the amount which is necessary to be taken in the diet, i.e. $10.6 \mathrm{~g}$ of linoleic acid and $1.3 \mathrm{~g}$ linolenic acid. The amount of dry matter from mealworms required to cover the need for linoleic acid per day was calculated at $205 \mathrm{~g}$ and that need to cover for linolenic acid at $708 \mathrm{~g}$. In the case of Zophobas morio, the respective amount of dry matter is $116 \mathrm{~g}$ for linoleic acid and $554 \mathrm{~g}$ for linolenic acid.

Detected contents of linoleic acid (5.16 g/100 g DM) and linolenic acid $(0.18 \mathrm{~g} / 100 \mathrm{~g}$ DM) for Tenebrio molitor were lower than these determined for Zophobas morio (linoleic acid content $9.15 \mathrm{~g} / 100 \mathrm{~g} \mathrm{DM}$, linolenic acid content $0.23 \mathrm{~g} / 100 \mathrm{~g} \mathrm{DM})$. In the case of dried meat, the content of linoleic acid is $1.02 \mathrm{~g} / 100 \mathrm{~g}$ and that of linolenic acid is $0.39 \mathrm{~g} / 100 \mathrm{~g}$ [Huis et al., 2013]. Therefore, to receive a daily dose of linoleic acid, up to 9 times less dry matter of superworm is needed in comparison to beef. On the other hand, for linoleic acid, less dry meat is needed than mealworm or superworm dry matter. Therefore, in order to minimise the weight of the dry matter as a nutritional dose (for example, in a person's special diet in places without access to a regular diet), a combination of both commodities can be recommended in the diet.

\section{CONCLUSIONS}

In this study, cholesterol, $\beta$-sitosterol, and stigmasterol were analysed in two edible insect species: mealworm (Tenebrio molitor) and superworm (Zophobas morio). When fed ad libitum, superworm had a higher content of sterols than mealworm. During the nutritional stress there was a statistically significant drop of the cholesterol content in both species. This suggests that cholesterol levels could be regulated in edible insects by proper nutrition. Although material of the animal origin is analysed, sterols of plant origin ( $\beta$-sitosterol, stigmasterol) have been detected. For this reason, it is possible to assume that both species could serve as a source of cholesterol (zoosterol) and phytosterols simultaneously (two in one). Further analysis proved a significant content of cholecalciferol, which was the same for both species, although the fat content differed. Another benefit is the lower weight of dry matter necessary to consume to cover the daily dose of linoleic acid compared to dried beef. The linoleic acid content of mealworm $(30.9 \mathrm{~g} / 100 \mathrm{~g})$ or superworm $(23.4 \mathrm{~g} / 100 \mathrm{~g})$ is comparable with, for example, chicken lard, pork lard or goose lard.

Based on the legalization of edible insects as a novel food in Europe since 2018, it is not a problem to include this commodity in the diet both in the hidden form (dry matter for food fortification) and in the visible form as an experience food.

\section{RESEARCH FUNDING}

This research was supported by the internal grant of TBU in Zlín [No. IGA/FT/2019/004] and project BUT in Brno [No. FEKT S-17-3934].

\section{CONFLICTS OF INTEREST}

The authors declare no conflict of interest.

\section{REFERENCES}

1. Adámková, A., Kouřimská, L., Borkovcová, M., Kulma, M., Mlček, J. (2016). Nutritional values of edible Coleoptera (Tenebrio molitor, Zophobas morio and Alphitobius diaperinus) reared in the Czech Republic. Potravinarstvo Slovak Journal of Food Sciences, 10(1), 663-671.

2. Adámková, A. (2017). Nutritional analysis and optimization of rearing of selected species of edible insects under conditions of the Czech Republic with regard to human health, dissertation theses. Prague, Czech Republic: Czech University of Life Sciences Prague, p. 108. 
3. Barroso, F.G., de Haro, C., Sánchez-Muros, M.J., Venegas, E., Martínez-Sánchez, A., Pérez-Bañón, C. (2014). The potential of various insect species for use as food for fish. Aquaculture, 422, 193-201.

4. Behmer, S.T., Nes, W.D. (2003). Insect Sterol Nutrition and Physiology: A Global Overview. Advances in Insect Physiology, 31, 1-72.

5. Cerritos, R. (2011). Grasshoppers in agrosystems: pest or food? CAB Reviews: Perspectives in Agriculture, Veterinary Science, Nutrition and Natural Resources, 6(017), 1-9.

6. Cerritos, R. (2009). Insects as food: an ecological, social and economical approach. CAB Reviews: Perspectives in Agriculture, Veterinary Science, Nutrition and Natural Resources, 4(027), 1-10.

7. Chakravorty, J., Ghosh, S., Jung, Ch., Meyer-Rochow, V.B. (2014). Nutritional composition of Chondacris rosea and Brachytrupes orientalis: Two common insects used as food by tribes of Arunachal Pradesh, India. Journal of Asia-Pacific Entomology, 17(3), 407-415.

8. Chakravorty, J., Ghosh, S., Megu, K., Jung, Ch., Meyer-Rochow, V.B. (2016). Nutritional and anti-nutritional composition of Oecophylla smaragdina (Hymenoptera: Formicidae) and Odontotermes sp. (Isoptera: Termitidae): Two preferred edible insects of Arunachal Pradesh, India. Journal of Asia-Pacific Entomology, 19(3), 711-720.

9. Chakravorty, J., Ghosh, S., Meyer-Rochow, V.B. (2011). Chemical composition of Aspongopus nepalensis Westwood 1837 (Hemiptera; Pentatomidae), a common food insect of tribal people in Arunachal Pradesh (India). International Journal for Vitamin and Nutrition Research, 81 (1), 49-56.

10. Decree No. 225/2008 Coll. (2008) (CZ) stipulating the requirements for food supplements and the fortification of food, as amended, (transposition of Directive of the European Parliament and of the Council 2002/46/EC on the approximation of the laws of the Member States relating to food supplements). Collection of Laws CZ 71/2008:3230.

11. Dobiášová, M. (2006). AIP - atherogenic index of plasma as a significant predictor of cardiovascular risk: from research to practice. Vnitřní lékařství, 52(1), 64-71 (in Czech).

12. EFSA. (2015). Risk profile related to production and consumption of insects as food and feed. EFSA Journal, 13(10), 4257$-4317$.

13. EFSA. (2010). Scientific Committee. Scientific Opinion on Dietary Reference Values for fats, including saturated fatty acids, polyunsaturated fatty acids, monounsaturated fatty acids, trans fatty acids, and cholesterol. EFSA Journal, 8(3), 1461.

14. Ekpo, K.E., Onigbinde, A.O., Asia, I.O. (2009). Pharmaceutical potentials of the oils of some popular insects consumed in southern Nigeria. African Journal of Pharmacy and Pharmacology, 3(2), $51-57$.

15. EN 12821:2009. (2009). Foodstuffs - Determination of vitamin D by high performance liquid chromatography - Measurement of cholecalciferol (D3) or ergocalciferol (D2). European Committee for Standardization: Brussel, Belgium.

16. Finke, M.D. (2004). Nutrient content of insects. In J.L. Capinera (Eds.), Encyclopedia of Entomology, Kluwer Academic Publishers, Dordrecht, The Netherlands, pp. 1563-1575.

17. Finke, M.D. (2002). Complete nutrient composition of commercially raised invertebrates used as food for insectivores. Zoo Biology, 21(3), 269-285.
18. Fontaneto, D., Tommaseo-Ponzetta, M., Galli, C., Risé, P., Glew, R.H., Paoletti, M.G. (2011). Differences in fatty acid composition between aquatic and terrestrial insects used as food in human nutrition. Ecology of Food and Nutrition, 50(4), 351-367.

19. Ghosh, S., Lee, S.M., Jung, C., Meyer-Rochow, V.B. (2017). Nutritional composition of five commercial edible insects in South Korea. Journal of Asia-Pacific Entomology, 20(2), 686-694.

20. Ikekawa, N., Fujimoto, Y., Ishiguro, M. (2013). Reminiscences of research on the chemistry and biology of natural sterols in insects, plants and humans. Proceedings of the Japan Academy Series B, Physical and Biological Sciences, 89(8), 349-369.

21. ISO 12966-2:2011. (2011). Animal and vegetable fats and oils - Gas chromatography of fatty acid methyl esters. International Organization for Standardization. Geneva, Switzerland, p. 15.

22. ISO 1442:1997. (1997) Meat and meat products - Determination of moisture content (Reference method). Geneva, Switzerland: ISO, p. 4.

23. ISO 1871:2009. (2009) Food and feed products -- General guidelines for the determination of nitrogen by the Kjeldahl method. Geneva, Switzerland: ISO, p. 7.

24. Jirák, R., Zeman, M. (2007). Vliv omega-3 a omega-6 nenasycených mastných kyselin na psychické poruchy (The Functions of Omega-3 and Omega-6 at Polynusaturatted Fatty Acids on Psychic Disorders). Česká a slovenská psychiatrie, 2(4), 6.

25. Józefiak, D., Józefiak, A., Kierończyk, B., Rawski, M., Świątkiewicz, S., Długosz, J., Engberg, R.M. (2016). Insects. A natural nutrient source for poultry. Annals of Animal Science, 16(2), 297-313.

26. Klowden, M.J. (2007). Physiological Systems in Insects. 2nd ed. Elsevier, Academic Press: Burlington, USA, p. 688.

27. Kulma, M., Kourimska, L., Plachy, V., Bozik, M., Adamkova, A., Vrabec, V. (2019). Effect of sex on the nutritional value of house cricket, Acheta domestica L. Food Chemistry, 272, 267-272.

28. Mariod, A.A., Abdel-wahab, S.I., Ain, N.M. (2011). Proximate amino acid, fatty acid and mineral composition of two Sudanese edible pentatomid insects. International Journal of Tropical Insect Science, 31(3), 145-153.

29. Mlcek, J., Rop, O., Borkovcova, M., Bednarova, M. (2014). A comprehensive look at the possibilities of edible insects as food in Europe - A Review. Polish Journal of Food and Nutrition Sciences, 64(3), 147-157.

30. Mondy, N., Corio-Costet, M.F., Bodin, A., Mandon, N., Vannier, F., Monge, J.P. (2006). Importance of sterols acquired through host feeding in synovigenic parasitoid oogenesis. Journal of Insect Physiology, 52 (9), 897-904.

31. Mourek, J., Mourek, Jr. J. (2011). Developmentally dependent and different roles of fatty acids OMEGA-6 and OMEGA-3. Prague Medical Report, 112(2), 81-92.

32. Nation, J.L. (2001). Insect Physiology and Biochemistry, 4. CRC Press, Boca Raton, USA, p. 496.

33. Nowak, V., Persijn, D., Rittenschober, D., Charrondiere, U.R. (2016). Review of food composition data for edible insects. Food Chemistry, 193, 39-46.

34. Oonincx, D.G.A.B., van Broekhoven, S., van Huis, A., van Loon, J.J.A. (2015). Feed conversion, survival and development, and composition of four insect species on diets composed of food by-products. PLoS ONE, 10, 1-20, art. no. e0144601. 
35. Pánek, J., Pokorný, J., Dostálová, J. (2002). Základy výživy a výživová politika. 1st ed. Vysoká škola chemicko-technologická: Prague, Czech Republic (in Czech).

36. Piironen, V., Lindsay, D.G., Miettinen, T.A., Toivo, J., Lampi, A.M. (2000). Plant sterols: Biosynthesis, biological function and their importance to human nutrition. Journal of the Science of Food and Agriculture, 80(7), 939-966.

37. Premalatha, M., Abbasi, T., Abbasi, T., Abbasi, S.A. (2011). Energy-efficient food production to reduce global warming and ecodegradation: The use of edible insects. Renewable and Sustainable Energy Reviews, 15(9), 4357 - 4360.

38. Ramos-Bueno, R.P., Gonzalez-Fernandez, M.J., Sanchez-Muros-Lozano, M.J., Garcia-Barroso, F., Guil-Guerrero, J.L. (2016), Fatty acid profiles and cholesterol content of seven insect species assessed by several extraction systems. European Food Research and Technology, 242(9), 1471-1477.

39. Ramos-Elorduy, J., Moreno, J.M., Vázquez, A.I., Landero, I., Oliva-Rivera, H., Camacho, V.H. (2011). Edible Lepidoptera in Mexico: Geographic distribution, ethnicity, economic and nutritional importance for rural people. Journal of Ethnobiology and Ethnomedicine, 7(1), 2.

40. Ravzanaadii, N., Kim, N.J., Kim, S.H., Choi, W.H., Hong, S.J. (2012). Nutritional value of Mealworm, Tenebrio molitor as food source. International Journal of Industrial Entomology, 25(1), 93-98.

41. Regulation (EC). (2001). No. 213/2001 of 9 January 2001 laying down detailed rules for the application of Council Regulation (EC) No 1255/1999 as regards methods for the analysis and quality evaluation of milk and milk products and amending Regulations (EC) No 2771/1999 and (EC) No 2799/1999. Official Journal of the European Communities, L 37, pp. 1-99.

42. Sabolová, M., Adámková, A., Kouřimská, L., Chrpová, D., Pánek, J. (2016). Minor lipophilic compounds in edible insects. Potravinarstvo Slovak Journal of Food Sciences, 10(1), 400-406.

43. Sánchez-Muros, M.J., de Haro, C., Sanz, A., Trenzado, C.E., Villareces, S., Barroso, F.G. (2016). Nutritional evaluation of Tenebrio molitor meal as fishmeal substitute for tilapia (Oreochromis niloticus) diet. Aquaculture Nutrition, 22(5), 943-955.

44. Simopoulos, A.P. (2002). The importance of the ratio of omega-6/omega-3 essential fatty acids. Biomedicine \& Pharmacotherapy, 56(8), 365-379.
45. Soxhlet, F. (1879). Die gewichtsanalytische Bestimmung des Milchfettes. Dingler's Polytechnisches Journal, 232, 461-465.

46. Stajić, S., Živković, D., Perunović, M., Šobajić, S., Vranić, D. (2011). Cholesterol content and atherogenicity of fermented sausages made of pork meat from various breeds. Procedia Food Science, 1, 568-575.

47. Tzompa-Sosa, D.A., Yi, L., van Valenberg, H.J.F., van Boekel, M.A.J.S., Lakemond C.M.M. (2014). Insect lipid profile: aqueous versus organic solvent-based extraction methods. Food Research International, 62, 1087-1094.

48. van Broekhoven, S., Oonincx, D.G.A.B., van Huis, A., van Loon, J.J.A. (2015). Growth performance and feed conversion efficiency of three edible mealworm species (Coleoptera: Tenebrionidae) on diets composed of organic by-products. Journal of Insect Physiology, 73, 1-10.

49. van Huis, A. (2016). Edible insects are the future? Proceedings of the Nutrition Society, 75(3), 294-305.

50. van Huis, A., van Itterbeeck, J., Klunder, H., Mertens, E., Halloran, A., Muir, G., Vantomme, P. (2013). Edible insects: Future prospects for food and feed security. 1st ed. Food and Agriculture Organization of the United Nations: Rome, Italy, p. 191 [http:// www.fao.org/3/i3253e/i3253e.pdf].

51. Velíšek, J. (2002). Chemie potravin (The Chemistry of Food). 2nd ed. OSSIS: Tábor, Czech Republic (in Czech).

52. Venugopal, V., Gopakuma, K. (2017). Shellfish: Nutritive value, health benefits, and consumer safety. Comprehensive Reviews in Food Science and Food Safety, 16(6), 1219-1242.

53. WHO (World Health Organization). (2004). A strategy to prevent chronic disease in Europe. A focus on public health action. The CINDI vision. WHO, Regional Office for Europe: Copenhagen, Denmark.

54. Zielińska, E., Baraniak, B., Karaś, M., Rybczyńska, K., Jakubczyk, A. (2015). Selected species of edible insects as a source of nutrient composition. Food Research International, 77, 460-466.

55. Zhang, Z., Liu, L., Xie, C., Li, D., Xu, J., Zhang, M., Zhang, M. (2014). Lipid contents, fatty acid profiles and nutritional quality of nine wild caught freshwater fish species of the Yangtze Basin, China. Journal of Food and Nutrition Research, 2(7), 388-394.

Submitted: Submitted: 19 December 2018. Revised: 27 February and 5 May 2019. Accepted: 27 May 2019. Published on-line: 3 July 2019. 